\title{
НЕКОЛКУ ПРАШАЊА ЗА ПОЕТИКАТА НА ЕСЕИТЕ НА ГОРАН СТЕФАНОВСКИ
}

\author{
Иван Антоновски \\ Независен истражувач \\ i.antonovski@gmail.com
}

Овој истражувачки труд е посветен на есеистичкото творештво на Горан Стефановски, кое досега не е одделно и поопстојно истражувано и коментирано од македонската книжевна наука. Сметајќи го есејот за одделен жанр, во анализата на поетиката на есеите на Стефановски констатираме дека неговиот есеистички текст со своите особености надминува дел од досегашните теориски одредби за есејот. Остварувајќи се како текст што припаѓа на метажанр/наджанр, есејот на Стефановски не може стриктно да се категоризира само преку постојните типологии на есејот, при што, меѓу другото, го препознаваме како одделен вид есеј - ренесансно-постмодернистички. Анализирајќ ја неговата поетика, се доаѓ до согледба дека есеистичкото творештво на Стефановски се развива од мини- или нацрт-есеј до хипересеј, при што во него, мизанабимски, како есеми се присутни повеќе видови есеј според постојните типологии. Трудот упатува и на неопходноста од натамошни читања и анализирања, во коі ќе се прикажат и ќе се вреднуваат и други естетски, поетички димензии на есејот на Стефаноски, на кои ова доминантно теориско исчитување сигнално упатува.

Клучни зборови: поетика, ренесансно-постмодернистички есеј, Горан Стефановски, категоризација, метажанр 


\title{
SEVERAL ISSUES ABOUT THE POETICS OF GORAN STEFANOVSKI'S ESSAYS
}

\author{
Ivan Antonovski \\ Independent researcher \\ i.antonovski@gmail.com
}

This research paper is dedicated to the essayistic work of Goran Stefanovski, which, so far, has not been studied and commented on by Macedonian literary scholars. Considering the essay as a specific genre, in the analysis of the poetics of Stefanovski's essays, it is concluded that his essay text with its peculiarities, outperforms the previous theoretical features of the essay. Being a text that belongs to a meta-genre/supra-genre, Stefanovski's essay cannot be strictly categorized only through the existing typologies, where it is, inter alia, recognized as a specific type of an essay - renaissance-postmodernist essay. Analyzing his poetics, one could conclude that Stefanovski's essayistic work advances from a mini or draft essay to a hyper essay, where like mise en abyme, several types of essays as structural parts of the essay are included, according to the existing typologies. The paper also points to the need for further readings and analyses in which other aesthetic and poetic dimensions of Stefanoski's essay will be presented and evaluated, signaled by this dominant theoretical analysis.

Keywords: poetics, renaissance-postmodernist essay, Goran Stefanovski, categorization, meta-genre 


\section{1 Уводна напомена}

Додека за драмските текстови на Горан Стефановски веќе може да се издвојат две фази на критичка рецепција (Кошка-Хот 2019), досега на неговото есеистичко творештво одделно внимание му е посветено само во два објавени труда (Младеновски 2005 и Смилевски 2019), при што ниту еден од нив не е одделно фокусиран на поетиката.

Оттука, очекувано, во отсуство на претходни книжевнокритички и книжевнотеориски осврнувања, уште при првичниот обид да се анализира и да се претстави поетиката на есеистичкото творештво на Стефановски, се отвораат низа прашања што заслужуваат внимание преку одделни студии за секое од нив. Затоа, во овој обид се издвоени само неколку од прашањата и се споделени потенцијални видувања, кои можат да бидат појдовна точка за натамошното исчитување на есеите на Стефановски, а кои едновремено водат и кон не многу познат теориски терен за есејот како жанр што „постојано ги надминува своите жанровски граници“ (Епштејн 1997: 8) и веќе не е само „среќна книжевна случајност“" (Epstein 1997: 11) и койнеж йо систием (Lukač 1973).

\section{2 Дали есејот на Стефановски е ренесансен или постмодернистички?}

Дилемите што беа присутни кај македонската книжевна наука во врска со едновременото присуство на постмодернистичките и модернистичките елементи во драмското творештво на Стефановски се иницијална каписла при исчитувањето на неговите есеи да се отвори прашањето за припадноста кон стилска формација.

На есеистичкиот терен, критичкото и аналитичко исчитување на опусот на Стефановски упатува кон анализирање на текстовите не само низ диоптриите на двете стилски формации на кои тој им беше современик туку и кон поширока стилско-формациска рамка што излегува од просторот на современата книжевност и го опфаќа и ренесансниот есеј. Но, притоа се наидува на бариерата од сознанието дека доминантните обележја на ренесансниот есеј претставуваат и конститутивни специфични одлики на есејот воопшто (Епштејн 1997), што наметнува неопходна претпазливост во определувањето на есејот на Стефановски исклучиво и строго како ренесансен.

Сепак, ако се проследат поетичките особености на есејот во различните стилски формации, а особено од постмодернизмот наваму, забележливи се тенденциите на отстапување од конститутивните специфични одлики на есеистичкиот текст, при што за тоа се ползуваат можностите што ги даваат формалната, методолошка и тематска слобода на есејот како жанр (Џепароски 2008) и одликата на динамична преобразба и адаптабилност кон нови дискурси. Наспроти тоа, есеистичкиот текст на Стефановски, напишан и објавен во период кога постмодернизмот во македонската книжевност беше во својот зенит, во голем дел ги содржи доминантните обележја на ренесансниот есеј, 
канонизирани и како конститутивни специфичности на есеистичкиот текст воопшто, меѓу кои и:

1. настојувањето предметот да се доживее и да се согледа оянайре (вклучително и преку експликација на личното искуство);

2. проблематизирањето на самиот процес на набљудување и спознавање;

3. комбинацијата на личниот став, литераризираниот, наративизираниот и разговорен израз со логичкото и емпириско просудување;

4. анегдотската предлошка и

5. естетичноста и поетичноста на јазикот.

Оттука, во одредена мера, поетички, есејот на Стефановски може да се анализира и да се вреднува и како ренесансен, поради ренесансниоти карак$\bar{u} е p$ на поетичките одлики на конкретното есеистичкото писмо. Есеизмот на Стефановски покажува дека во голем број остварувања есејот како жанр сѐ повеќе отстапува од своите конститутивни особености, сепак, со изразена литерарност, тие може и натаму да се ползуваат, а текстот да ги претставува највисоките поетички достоинства на есејот на своето книжевно време. Или, со други зборови: покажува дека есејот не мора нужно да бег̄a од некои свои дамнешни поетички особености за да биде дел од современиот книжевен контекст. Но, едновремено, и ја негира минатовековната одредба на Теодор Адорно дека „актуелноста на есејот е актуелност на нешто анахронистичко“ (Адорно 1983: 224).

Уште поважно во овој контекст е што при анализа на тематско-мотивски план, кога во исчитувањето до израз доаѓ гносеолошката доминанта во есејот на Стефановски, неминовно е да се забележи дека во него доминира ренесансното буяење на човеко $\bar{u}$, што и клучно упатува на можноста и потребата тој да се анализира (и) преку особеностите на ренесансното писмо.

Но, есејот, како и секој друг книжевен жанр, еволуира и не подлежи на непроменливи поетички начела. Впрочем, од постмодернизмот наваму, еволуцијата на есејот како „една од најфлексибилните и најадаптибилни од сите книжевни форми“ (Cuddon 1992: 307), се чини се одвива и побрзо отколку онаа на некои други жанрови, што подразбира и модификување/менување на некои од неговите канонизирани особености, детерминирано од творечката, поетички димензионирана инвентивност на есеистот. Во таа насока, есејот на Стефановски, и покрај присуството на најголемиот дел од ренесансните особености, едновремено и отстапува од ренесансниот канон, и тоа во однос на фокусирањето на само еден топос и илузијата на антисистематичност. Поконкретно, во голем дел од есеите на Стефановски, иако има еден носечки/главен топос, сепак, истовремено присутни се и други топоси, кои се во цврста синтеза со носечкиот и претставуваат своевидни поттопоси. Конкретен пример во кој е јасно согледлива ваквата поетичка одлика е есејот Приказни оя Дивиоти Исйок (Стефановски 2005: 59-93), во којшто (пот)топосите се мизанабимски присутни - преку одделни йриказни што ја сочинуваат ириказнайа на есејот како целина. Не помалку согледливо е и во есејот За намайа ириказна (ibid., 7-35), со слична структурна поставеност во однос на топосите, при што секој (пот) топос содржи одделно (пот)прашање, со што се адресира комплексноста на 
топосот што е носечки во конкретниот текст, но и во севкупното есеистичко творештво на Стефановски. Ова најверојатно најилустративно е согледливо во сѐ уште необјавениот есеј Искра шито се измолкнува (Stefanovski 2018). ${ }^{1}$

Поради ваквиот комплексен творечки приод со перципирање и фокусирање на повеќе (пот)топоси во текстот, есејот на Стефановски се чини дека отстапува и од ренесансниот дискретен минимализам. Поконкретно, дискретниот минимализам е присутен во рамките на внатрешната мала йриказна или gел-йриказна во есејот. Но, не и во рамките на севкупната йриказна на есејот - со неа Стефановски значително ги пречекорува границите на ренесансниот минимализам. Истовремено, отсуството на илузијата на антисистематичност

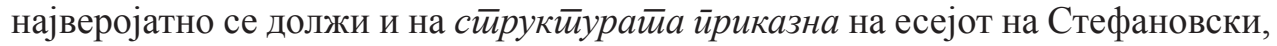
поради настојувањето видувањата и пораките на есеистот да се пренесени со хармонична и хронолошки логична градација во текстот.

Отсуството на овие неколку ренесансни, а истовремено и конститутивни одлики на есејот до степен на присуство на обележја што се нивни опозити, уште еднаш потврдува дека Стефановски се вбројува меѓу есеистите кои со својот израз и со својата творечка постапка не само што ги надградуваат туку и ги менуваат и ги ставаат на тест книжевнотеориските канони. Но, истовремено и уште еднаш укажува дека може и треба да еволуираат не само поетичките решенија туку и дефинициите и теоретските согледби за поетиката на есејот, следејќи ја еволуцијата на самиот есеистички текст, иако нема сомнение дека е тешко да се утврди сеопфатна и финалистичка одредба за сето она што e differentia specifica на есејот како жанр.

Отстапувањата од неколкуте ренесансни и конститутивни специфични одлики на есеистичкиот текст и истовременото присуство на постмодернистички техники и својства, овозможуваат есејот на Стефановски да се анализира и да се вреднува и како постмодернистички. Од една страна, севкупниот есеизам на Стефановски може да се исчитува и преку големата постмодернистичка тема крај на г̄олемите наращии, додека од друга страна, присуството на интертекстуалноста и на автореференцијалноста, а во Искра шйо се измолкнува дури и на интермедијалноста, претставува евидентна постмодернистичка поетичка рефлексија.

Но, сепак, мора да се има и предвид дека сето она што книжевната теорија го припишува за техники и својства на постмодернистичкото писмо, не е (во целост) непознато во книжевноста во претпостмодернистичкиот период. Впрочем, не може да се рече дека цитатноста, а со тоа и интертекстуалноста и автореференцијалноста, се постмодернистички ексклузивитет и дека во целост се отсутни во ренесансниот есеј.

Затоа, при анализирањето на есејот на Стефановски се доаѓ до стојалиште дека не треба да се настојува на негова целосна припадност кон конкретна стилска формација. Есејот на Стефановски е подеднакво ренесансен и постмодернистички, дотолку што нужно е да се отстапи од досегашните типологии во книжевната наука и да се категоризира како ренесансно-постмодернистички.

\footnotetext{
${ }^{1}$ Текстот Искра шито се измолкнува (The Spark Which Escapes) е последниот есеј на Стефановски, но досега не е објавен. Во нашите анализи го користиме ракописот од личната архива на Горан Стефановски, по согласност од семејството Стефановски.
} 
Заземањето на ваквото стојалиште не е бегство од критичкотеоретичарска одговорност, туку инсистирање на темелно исчитување и претставување на опусот на Стефановски, особено во отсуство на досега јасно дефинираните поетички разлики меѓу есеите од различните стилски формации и имајќи предвид дека при создавањето есеистички текст, користејќи го есеистичкиот простор на слободата, врвните есеисти, во чиј ред е Стефановски, не робуваат на она што теоријата го нормира како специфика на есејот ниту исклучиво на канонот на формацијата.

Евидентно е дека самиот Стефановски во својот есеј е ослободен од определбата за формациска припадност, дотолку што на повисоките интерпретативни рамништа на текстот се забележува дека таа дури и му е туѓа. Наместа во текстот, творечки интуитивно, тој и ја заобиколува сйайицай $а$ на формацискиот канон, додека некои техники ги ползува не за да биде или да не биде постмодернист, туку за да го постигне посакуваниот ефект кај реципиентот/ адресатот (како, на пример, интермедијалноста во Искра шимо се измолкнувa) или поради нужноста што произлегува од неговиот пристап - својот став за топосот да го прикаже преку осврнување кон (пот)топосите - ириказна$\bar{u} a$ да се раскаже преку низа внайрешни иоомали ириказни. Токму тоа, како и евидентното отстапување од канонизираната схема на есејот, наложува да се излезе од досегашните типологии и да се инсистира есеистичкиот текст на Стефановски да се вреднува и да се исчитува надвор од тесните стилско-формациски рамки за него, како ренесансно-постмодернистички.

\section{3 На кој вид есеј му припаѓa есеистичкиот текст на Стефановски?}

Категоризирањето на есеистичкиот текст на Стефановски како ренесансно-постмодернистички едновремено го отвора и прашањето за негова категоризација според досегашните типологии на есејот, иако она што досега е присутно во референтната теориска литература, пред сѐ, е обид за типологизација.

Следејќи го досега единствениот обид за типологија на македонскиот есеј (Ќуулавкова 2002), доминантен дел од есеите на Стефановски, според жанровско-стилските принципи, припаѓаат на видот есеј беседа, а друг, многу помал дел, на видот есеј колумна, додека присутен е и есејот писмо, односно епистоларниот есеј, како на пример, есејот Писмо яо внукай $а$ (Стефановски 2018). ${ }^{2}$

Но, ваквата категоризација е прифатлива како заокружена само на почетното ниво на критичкотеориското анализирање на есеистичкиот опус на Стефановски. Кога тој се исчитува структурно и фрагментарно, поради неговата мизанабимска поставеност со йриказна во ириказна, односно есеј во есеј, во рамките на есејот беседа на Стефановски, како есема егзистира и есејот расказ, како и есејот драмски дијалог, кој не е евидентиран како одделен вид есеј во досегашните типологии. А, најчесто присутната есема, всушност, е есејот анегдота, кој исто не е канонизиран меѓу видовите есеј, барем не во досегаш-

\footnotetext{
${ }^{2}$ Видот есеј-интервју овојпат не е земен предвид поради воздржаност во однос на поимањето на интервјуто како есеј.
} 
ните обиди за типологизација што се консултирани при ова осврнување на опусот на Стефановски (Lopate 1995, Ќулавкова 2007 и Божић 2005).

Досегашното теориско изоставање/непоимање на есејот анегдота најверојатно се должи и на тоа што анегдотската предлошка е една од конститутивните одлики на есејот, присутна уште во почетниот модел на есеистичкиот текст, но во есеизмот на Стефановски таа добива сосема поинакви димензии. Не само што како есема е исклучително фреквентна во текстот туку и преку неа Стефановски создава орамска сийуаиија со која таа постанува/преминува најчесто во есема есеј расказ, што, на пример, може да се согледа во есеите За нашайа ирриказна (Стефановски 2005: 7-35) и Расийан ииелефон (Стефановски 2010: 117-132). Есемата есеј анегдота, која Стефановски би ја нарекол мала ириказна, во рамките на неговиот есеистички текст постепено се трансформира во есема есеј расказ - иогоолема йриказна која во поттекстот и структурата е едно од главните јадра на текстот - носечки, конститутивен елемент на г̃лавнайа йриказна во севкупното есеистичко творештво на Стефановски.

Оттука, преку микрочитањето во кое се препознаваат есемите што некогаш се на границата меѓу мини- или нацрт-есејот ${ }^{3}$ и канонизираните видови есеј, а се присутни како есеј во есеј, се препознава и комплексниот творечки, поетички димензиониран процес, од кој произлегува маестралниот есестички текст на Стефановски. Дотолку што на текстот може да му се пристапи и структуралистички и генезата на неговата структура да се анализира преку видовите есеј што егзистираат во него како есеми - како мали или gел-йриказ$н и$, кои ја сочинуваат главната есеизирана ириказна.

Ваквата структурна комплексност на есејот на Стефановски, всушност, е и потврда дека, кога се користи постапката текст во текст, „двојната кодираност на определени единици на текстот, која се изедначува со уметничката условност, води кон тоа, основното пространство на текстот да се восприема како реално“ (Лотман 2003: 53). Кај Стефановски кодираноста некогаш е и повеќе од двојна, но едновремено, изразено присутна е потребата да се убеди реципиентот дека есеизираното е реално и дека йриказнайа е вистинита, при што во функција на тоа се и мајсторски остварените интертекстуалност и автореференцијалност, особено преку есеите анегдоти и есеите раскази, присутни како есеми, при што неретко присуството на есејот расказ ги надминува поетичките димензии на есемата.

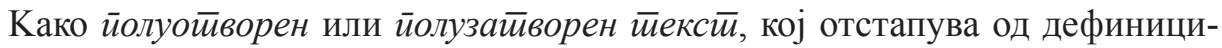
ите на Умберто Еко за отворен и затворен текст (Eko 2001), есејот на Стефановски е во интеракција со реципиентот, во кој треба да му ги пренесе вистината и пораките од светогледот на есеистот. Но, тоа Стефановски го остварува суптилно, естетизирано и одмерено. Најверојатно затоа, есејот со неговата ириказна е со

структура при која еден текст се дава како непрекинато раскажување, а другите се воведуваат во него во посебен фрагментарен вид [есеми-есеи - заб.

\footnotetext{
${ }^{3}$ Мини- или нацрт-есејот може да се смета за прва фаза на есеистичкото творештво на Стефановски. Кон ваквата форма припаѓаат конзервираниие имиресии, кои во 1974, 1979 и 1980 година се објавувани во списанието Разг̄леяи, потоа објавени и во книгата Конзервирани имйресии (Стефановски 2004).
} 
наша]. Се претпоставува дека читателот [реципиентот - заб. наша) ќе ги развие зрната од другите структурни конструкции во текстот (ibid., 59).

Притоа, во есејот на Стефановски, во согласност со очекувањата на Јуриј Лотман од мизанабимскиот текст, „сличните вклучувања може да се читаат и како еднородни со текстот што ги опкружува и како различни од него“ (ibid., 59).

Оттука, формално, најиздржано е во рамките на постојните типологии, есеистичкиот текст на Стефановски доминантно да се анализира и да се интерпретира како есеј беседа, кој во себе како есеми ги содржи другите типови есеј сврзани со семантичките својства на другите жанрови. Но, мора да се има предвид дека, суштински, во творештвото на Стефановски беседата е само повод да се напише есеј. Ако се изземе податокот дека станува збор за беседа, кој е наведен по некои од насловите (напомена дека е говор за одреден настан) и ако се изостават само некои од уводните или од завршните реченици што се поврзани со формалниот карактер на текстот, есејот на Стефановски, поетички, значајно ги надминува особеностите на беседата.

На повисоко интерпретативно рамниште, следејќи ја градацијата на/во текстот, дел од есеите беседи на Стефановски примарно може да се категоризираат и како есеи раскази - во нив есејот расказ како јадро на текстот е многу

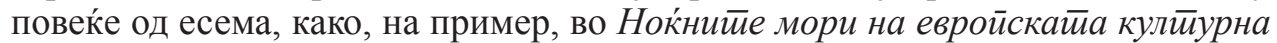
йолийика (Стефановски 2005: 39-55), во кој текстот во голема мера е во наратолошките рамки на расказот. Есејот Кав̄̄a со Кафка (Стефановски 2010: 157-170), пак, е исклучителен антологиски пример за есеј драмски дијалог, со исклучително вешто ползувана интертекстуалност - есеј драмски дијалог во кој во целост е изоставен формалниот образец на беседата.

Од друга страна, меѓу видовите есеј, според тематските принципи, есеистичкиот текст на Стефановски, иако доминантно е културолошки, сепак, во поширока рамка, соодветна на неговата тематско-мотивска волуменозност и комплексност, која доминантно задира во есенцијални идентитетски прашања и дилеми, на повисоко интерпретативно рамниште, суштински, едновремено е и филозофски, доминантно гносеолошки, но и антрополошки. Или, попрецизно: со отстапување од канонизираното во книжевната теорија, текстот на Стефановски е културолошки и филозофско-антрополошки, односно гносеолошко-антрополошки есеј, што особено се согледува доколку се анализираат есеизираните опсервации на конкретни идентитетски прашања и дилеми.

Но, при обидот есејот на Стефановски да се категоризира во видовите есеј според стилските принципи, се наидува на бариера од досегашните типологии, бидејќи тој едновремено е и наративен, и дескриптивен, и аргументативен, додека книжевната теорија упатува на одделни видови есеј според секој од овие принципи, како стилски особености на текстот. Приказнайа на/во

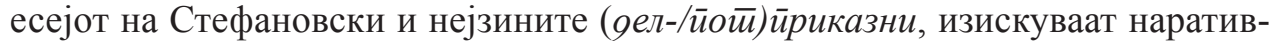
ност, а во нивното текстуално окружување и во нив Стефановски инсистира и на подетална описност и прикажување слики (дескрипција). Ова негово инсистирање се должи и на потребата за целосно пренесување на контекстот и поттекстот до реципиентот и поттикнување на дијалогот меѓу него и есеис- 
тичкото Јас, кое се води внатре во самиот есеј. И, исто толку важно, не само што gел-йриказнийе и дескрипцијата се илустративни аргументи во есеи-

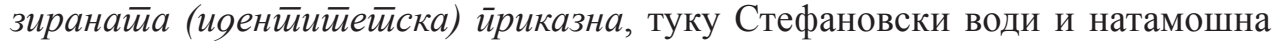
расправа со директно изложување аргументи за своите стојалишта, кои се клучни за остварување на поентирачките пораки. Сето ова ја оформува стилската комплексност на есејот на Стефановски, што придонесува за негово развивање од мини- или нацрт-есеј, остварен со конзервиранийе имйресии

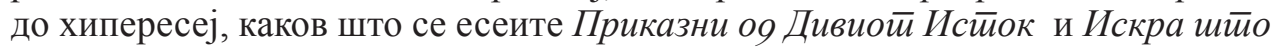
се измолкнува.

Овие согледби и оцени упатуваат кон констатацијата дека постојните типологии на есејот се претесни за да се одреди преку нив стриктно и финалистички припадноста на есеистичкиот текст на Стефановски кон зададени/ дефинирани видови есеј и со тоа да се исцрпат сите можности, што, секако, е предизвик и при исчитувањето на есеи од други знаменити есеисти од изминатите неколку децении. Оттука, овој обид за категоризирање на есеите на Стефановски е само назнака/почеток на остварувањето на потфат во таа насока, што може и треба да продолжи за да се дојде и до поконкретни вреднувачки видувања, со себе носејќки го и предизвикот еволуцијата на есејот да биде (про)следена и од еволуција на книжевнотеоретските опсервации и стојалишта за него како жанр.

\section{4 Дали текстот на Стефановски останува есеј и кога во него доминираат семантичките својства на некој друг жанр?}

Ваквиот теориски и интерпретациски приод кон есеистичкиот опус на Стефановски, преку обид за неговото категоризирање според постојните типологии на есејот, особено во корелација со особеностите на другите жанрови, очекувано го наметнува и прашањето дали текстот на Стефановски останува есеј и кога во него доминираат семантичките својства на некој друг жанр - дали може целосно да се разграничи неговата жанровска определеност

Без ни малку заобиколување, критичкотеорискиот прочит упатува кон позитивен одговор на ова прашање. Стефановски, водејќ нарација во есеистичкиот текст, создава наративно сврзувачко ткиво, кое семантичките својства од различните жанрови ги обединува во есеистичка целина. Но, тоа и не изненадува во опусот на есеист книжевник со творечка ерудиција, бидејќи „жанровската поливалентност и интердисциплинарноста, не се само право туку и обврска на есеистичкото творештво“ (Епштејн 1997: 20).

Во есејот Стефановски настапува не само од позиција на есеист - опсерватор и критичар - туку и од позиција на есеист - наратор на йриказнай $а$, кој успева со нарацијата во текстот, но и во поттекстот, цврсто да ја воспостави

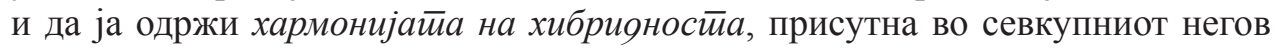
есеистички опус. Затоа, иако неговиот есеј не е (само) фикција, може да се анализира и како нарација, која подлежи на фокализација, но атипична за книжевната теорија - позиционирана на границата меѓу нулта и внатрешна фокализација. 
По игра на судбината, најмаестрално Стефановски сето ова го покажа или, посоодветно речено, го потврди во есејот Искра шимо се измолкнува, во кој, критички препрочитувајќ́ го своето претходно есеистичко творештво, го инкорпорира и дури го надградува сето она што е есенцијално во неговите есеи од двете децении пред тоа и со антисистематичен жанр од него прави систем, поврзувајќи го и со своето драмско творештво и со својата автобиографија. Всушност, Искра шито се измолкнува може да се вреднува, да се интерпретира и да се исчитува, а со тоа и да се категоризира и како есеј роман - најверојатно и прв во современата македонска книжевност.

Но, сублимирајќи го сето ова, се доаѓа до заклучок дека обидот за категоризирање на есејот на Стефановски меѓу типовите есеј сврзани со семантичките особености на другите жанрови ја потврдува тезата дека (особено) во опусот на ерудитот есеист што владее со литерарноста, есејот може да биде и метажанр, односно наджанр (Lukić 2001 и Ефтимоска 2011). Иако, суштин-

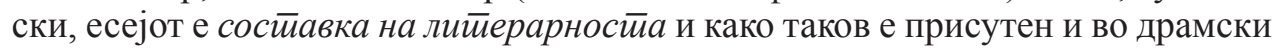
текстови и во подолги прозни книжевни форми, особено романи, во опус со естетски квалитети каков што е оној на Стефановски, тој се остварува како жанр што во себе ги содржи другите жанрови и нивните семантички својства, иако не подразбира однапред поетички зададена синхронизираност на нивна истовремена присутност во рамките на текстот. Оттука и останува отворено прашањето дали воопшто може прецизно и недвојбено да се категоризира оној есеј што во себе ги содржи семантичките особености на сите други жанрови.

\section{5 Наместо заклучок}

Во овој обид да се дојде до одговорите на неколку книжевнотеориски прашања за поетиката на есеите на Горан Стефановски, всушност, едновремено се отвораат и низа други прашања на кои е нужно натаму да им се посвети внимание. Но, овој обид веќе е доволен за да упати кон заклучокот дека есеистичките текстови на Стефановски, со своите комплексни поетички основи, ги негираат определбите и видувањата дека пред силата на големата естетика есејот може да биде „само претходник, и никаква самостојна вредност не би можела тука да се најде за него“ (Lukač 1973: 53). Есејот на Стефановски не само што не е и не може да се интерпретира и да се вреднува само како

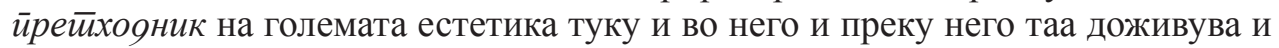
конкретно остварување.

Затоа, овој обид и обврзува јасно да се нагласи:

1. Есеј како оној на Стефановски, кој во себе ја апсорбира сета естетска есенцијалност што им се припишува на другите жанрови кои формално се вреднуваат за високоестиейски, не може да биде од другата страна на естетиката. Тој има самостојна вредност, дотолку повеќе што претставува и одделен

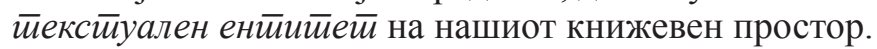

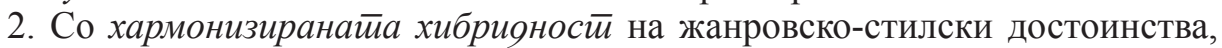
која преку севкупниот опус на Стефановски прераснува во нов иеексииуален

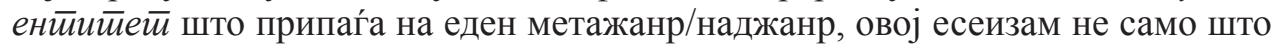
не е оддалечен од големата естетика туку и ја содржи во себе како кохезив- 
но поетичко јадро. Впрочем, беа неа севкупната поетичка комплексност на структурата на есејот на Стефановски и не би била остварлива.

3. Големата естетика е сврзувачкото ткиво меѓу сето она што Стефановски го внесува во текстот за да ја раскаже есеизираната йриказна. Само со ползување на големата естетика во рамките на творечкиот процес на (пре) создавање на текстот, може да се оствари текстуалното единство на поетички комплексните есеми и внатрешните стилско-жанровски трансформации во есејот на Стефановски.

Ваквите оцени обврзуваат при натамошните навраќњња кон поетичките прашања што овојпат се отворени, сеопфатно да се прикажат и да се вреднуваат и други естетски, поетички димензии на есејот на Стефаноски, на кои при ова доминантно теориско исчитување најверојатно само сигнално се упатува. Затоа што есејот на Стефановски не се движи по маргините на големата естетика, туку е во нејзиното средиште - врз неа и со неа е изградена севкупната негова поетика.

\section{Библиографија}

Адорно, Т. (1983). Есејот како форма. Треӣа Прогррама, 14-15: 207-225.

Божић, J. (2005). Есеј - фикција унутар истине. Гласник, 1: 227-249.

Епштејн, М. (1997). Есеј. Београд: Народна књига, Алфа.

Ефтимоска, Т. (2011). Есејой (макеоонско искустиво). Скопје: Македонска реч.

Лотман, М. J. (2003). Текст во текст. Во К. Куулавкова (прир.). Теорија на иниеер-

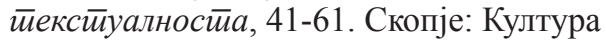

Кошка, Хот, Р. (2019). Горан Стефановски (1952-2018). Во З. Анчевски (уред.). Кни-

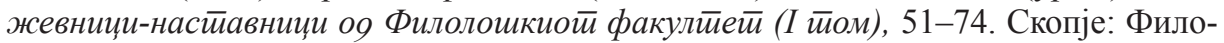
лошки факултет „Блаже Конески“.

Младеновски, Р. (2005). За мудрата и автентична македонска приказна. Современосй, 4: $127-131$.

Стефановски, Г. (2004). Конзервирани имйресии. Скопје: Темплум.

Стефановски, Г. (2005). Приказни оя Дивиой Истиок. Скопје: Табернакул.

Стефановски, Г. (2010). Кавг̄a со Кафка и яруг̄и есеи. Скопје: Табернакул.

Кулавкова, К. (2002). Мала теорија: егзотичен од по рабовите на книжевноста : поетика на есејот и прилог во македонскиот есеј. Во В. Стојчевска-Антиќ (уред.). Маке-

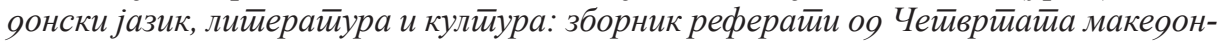
ско-северноамериканска слависиичка конференција за макеоонисииика, 191-207. Скопје: Универзитет „Св. Кирил и Методиј“.

Куулавкова, К. (прир.). (2007). Поимник на книжевнайа ӣеорија. Скопје: Македонска академија на науките и уметностите.

Џепароски, И. (2008). Филозофијата и поетиката на есејот. Во И. Џепароски (уред.). Макеоонскиот̄ есеј, 5-19. Битола: Микена.

Cuddon, J.A. (1992). A Dictionary of Literary Terms and Literary Theory. London: Penguin Books.

Eko, U. (2001). Granice tumačenja. Beograd: Paideia.

Epstein, J. (ed.). (1997). The Norton Book of Personal Essays. New York: W.W. Norton \& Company. 
Lopate, P. (ed.). (1995) Art of Personal Essay: an Anthology from the Classical Era to the Present. New York: Anchor Books.

Lukač, G. (1973). Duša i oblici. Beograd: Nolit.

Lukić, J. (2001). Metaproza: Čitanje žanra. Beograd: Stubovi kulture.

Stefanovski, G. (2018). The Spark Which Escapes (narratives between hammer and anvil). Ракопис од лична архива.

Смилевски, Г. (2019). Ставовите на Горан Стефановски за идентитетот и за идентитетските наративи. [Интернет] Philological Studies. 17(2): 160-172. Достапно на: https://journals.ukim.mk/index.php/philologicalstudies/article/view/323/253 [Пристапено на: 10.1.2020]

Стефановски, Г. (2018). Писмо до внуката. Факулиеейи [Интернет] 28 ноември. Достапно на: https://www.fakulteti.mk/news/28112018/pismo-do-vnukata---goranstefanovski [Пристапено на: 23.2.2020] 